\title{
INSTRUMEN ASESMEN BAHASA INGGRIS SMP PESERTA PPP BAHASA INGGRIS UNIVERSITAS NEGERI SURABAYA
}

\author{
Fauris Zuhri \\ Universitas Negeri Surabaya, Surabaya \\ fauriszuhri@unesa.ac.id
}

\begin{abstract}
Abstrak: Penelitian ini mengangkat masalah bagaimana upaya-upaya untuk meningkatkan kemampuan peserta Program Pengalaman Pembelajaran (PPP) Program Studi Pendidikan Bahasa Inggris Unesa dalam merencanakan, mengembangkan, dan menerapkan instrumen asesmen otentik. Berdasarkan rumusan masalah tersebut, maka tujuan penelitian yang diharapkan mendeskripsikan kemampuan peserta PPP Program Studi Pendidikan Bahasa Inggris Unesa dalam merencanakan, mengembangkan, dan menerapkan instrumen asesmen otentik. Oleh karena itu salah satu output (luaran) yang dihasilkan ialah mahasiswa mampu menyusun instrumen asesmen/penilaian pembelajaran Bahasa Inggris. Jenis penelitian yang digunakan ialah deskriptif kualitatif.
\end{abstract}

Kata kunci: program pelatihan guru, instrumen asesmen, perencanaan pembelajaran

Abstract: The purpose of research is how participants of teacher training program increase their ability to compose assessment instruments in level of planning, developing, and implementing. It relates with the research question: how do the participants of tecaher training program increase their ability to compose assessment instruments in level of planning, developing, and implementing? This research is conducted to the students of English Department of Faculty of Language and Arts the State University of Surabaya. It is expected to increase their ability in composing English assessment instruments in junior high school level. Descriptive qualitative research is implemented.

Keywords: Teacher Training Program, assessment instruments, lesson plan

\section{PENDAHULUAN}

Asesmen merupakan bagian yang tidak terpisahkan dari proses pembelajaran. Artinya asesmen harus dilakukan untuk mengetahui tingkat keberhasilan siswa atau tingkat pencapaian kompetensi yang telah dijabarkan di rencana pelaksanaan pembelajaran (RPP). Pencapaian kompetensi tersebut sudah tentu sangat penting diketahui oleh siswa, guru, orang tua siswa dan para pemangku kepentingan lainnya demi tercapai tujuan pendidikan yang telah dicanangkan. Oleh karena itu guru sudah seyogyanya menerapkan bentuk-bentuk asesmen yang mampu mengukur tingkat keberhasilan 
terhadap kompentensi dan/atau kemajuan siswa.

Ada keterkaitan dan interdependensi yang sangat erat antara pembelajaran dengan asesmen. Untuk mengetahui tingkat keberhasilan, efektivitas dan efisiensi sebuah program pembelajaran dalam mewujudkan tujuan yang disasar maka peserta harus melakukan asesmen. Asesmen dapat dilakukan terhadap kelebihan dan kekurangan dari rencana pelaksanaan pembelajaran dan prestasi siswa terhadap materi pelajaran.

Hakikat pola penilaian yang dikembangkan dalam Kurikulum yang berbasis kompetensi lebih diarahkan pada pengukuran yang seimbang pada ranah kognitif, afektif, dan psikomotor, serta menggunakan prinsip berkesinambungan dan otentik guna memperoleh gambaran (profiles) keutuhan prestasi dan kemajuan belajar siswa.

Berdasarkan pengamatan di lapangan dan dari hasil observasi peneliti di Program Pengalaman Pembelajaran program studi Pendidikan Bahasa Inggris Universitas Negeri Surabaya, para peserta masih cenderung menggunakan model tes dalam asesmennya, baik dalam menilai proses dan hasil pembelajaran, tanpa menghiraukan apakah itu mengukur aspek kognitif, afektif, maupun psikomotor. Di beberapa tempat bahkan dapat dengan mudah menemukan kumpulan soal-soal, sekalipun soal itu tidak atau belum baku atau layak untuk digunakan. Peserta juga menggunakan tes yang diperjualbelikan di pasaran bebas, yang merupakan tes yang kurang baik, dan tidak sesuai dengan kompetensi yang dituntut dalam kurikulum.

Sebagai contoh kasus ialah, bahwa kegiatan pembelajaran yang melibatkan kinerja siswa dalam melakukan percobaan sudah sering diterapkan, namun terhadap kinerja siswa tersebut belum pernah dilakukan penilaian. Menurut pengakuan sejumlah peserta PPP Bahasa Inggris Unesa hal ini disebabkan pelatihan yang secara khusus membahas penerapan penilaian otentik belum pernah diikuti oleh para peserta secara komprehensif. Kondisi tersebut mengakibatkan pengetahuan, pengalaman maupun penguasaan peserta terhadap proses asesmen masih kurang.

Berdasarkan uraian di atas kiranya perlu diadakan perlatihan tentang asesmen otentik berdasarkan kompetensi dasar yang tertera dalam silabus masingmasing mata pelajaran, karena dapat menambah wawasan guru tentang bentuk asesmen/penilaian alternatif. Penelitian ini difokuskan pada asesmen otentik pada para peserta PPP Bahasa Inggris Universitas Negeri Surabaya 2016 dimana berdasarkan análisis situasi yang telah dilakukan oleh peneliti bahwa para peserta tersebut belum mampu mengembangkan dan melaksanakan asesmen otentik. Hal ini sudah barang tentu dapat berdampak pada kurangnya kualitas lulusannya. Peneliti memandang perlu sesegera mungkin diadakan pelatihan asesmen otentik ini karena sistem penilaian ini dapat dijadikan pendukung peningkatan kualitas peserta PPP Bahasa Inggris.

Berdasarkan batasan paparan latar belakang serta identifikasi masalah yang dikemukakan di atas, maka ada tiga permasalahan yang dapat diformulasikan sebagai: pertama, bagaimana meningkatkan kemampuan peserta PPP Program Studi Pendidikan Bahasa Inggris Unesa dalam merencanakan instrumen asesmen otentik? Kedua, bagaiamana meningkatkan kemampuan peserta PPP Program Studi Pendidikan Bahasa Inggris Unesa dalam mengembangkan instrumen asesmen otentik? Ketiga, bagaiamana 
meningkatkan kemampuan peserta PPP Program Studi Pendidikan Bahasa Inggris Unesa dalam menerapkan instrumen otentik asesmen?

Berdasarkan paparan dan rumusan masalah sebelumnya, pada dasarnya tujuan yang ingin dicapai dalam kegiatan penenelitian ini adalah untuk meningkatkan kualitas kegiatan PPP Bahasa Inggris Unesa 2016. Secara lebih spesifik, tujuan yang ingin dicapai dalam kegiatan ini dapat dinyatakan sebagai berikut: pertama, mendeskripsikan kemampuan peserta PPP Program Studi Pendidikan Bahasa Inggris Unesa dalam merencanakan instrumen asesmen otentik. Kedua, mendeskripsikan kemampuan peserta PPP Program Studi Pendidikan Bahasa Inggris Unesa dalam megembangkan instrumen asesmen otentik. Ketiga, mendeskripsikan kemampuan peserta PPP Program Studi Pendidikan Bahasa Inggris Unesa dalam menerapkan instrumen asesmen otentik

Pembelajaran berbasis kompetensi dirancang dan dilaksanakan sesuai prinsip-prinsip yang mendasarinya, maka keberhasilan proses pengajaran dan pembelajaran harus dinilai berdasarkan asesmen otentik. Pierce dan O'Malley. 1996 mendeskripsikan asesmen otentik sebagai berbagai bentuk asesmen yang mencerminkan pembelajaran, prestasi, motivasi dan sikap siswa terhadap berbagai aktivitas pengajaran dan pembelajaran selama pembelajaran (1996: 26). Hal ini jelas mengindikasikan bahwa asesmen otentik harus dilakukan secara komprehensif, objektif serta berkesinambungan. Pierce dan O'Malley (1996: 27) mengatakan bahwa asesmen/penilaian otentik mimiliki enam karateristik: constructed response, higher-order thinking, authenticity, integrative, process and product, and depth versus breadth.
Menurut (Hart, 1994: 14), asesmen otentik yaitu suatu asesmen yang melibatkan siswa di dalam tugas-tugas otentik yang bermanfaat, penting, dan bermakna. Berbagai tipe asesmen otentik menurut Hibbard (2000: 18) adalah: 1) asesmen kinerja, 2) observasi dan pertanyaan, 3) presentasi dan diskusi, 4) proyek dan investigasi, dan 5) portofolio dan jurnal.

Pada hakikatnya, kegiatan penilaian yang dilakukan tidak semata-mata untuk menilai hasil belajar siswa saja, melainkan juga berbagai faktor yang lain, antara lain kegiatan pengajaran yang dilakukan itu sendiri. Artinya, berdasarkan informasi yang diperoleh dari penilaian dapat pula dipergunakan sebagai umpan balik penilaian terhadap kegiatan pengajaran yang dilakukan (Nurgiyantoro, 2001: 4)

\section{METODE PENELITIAN}

Penelitian ini menggunakan pendekatan kualitatif dan jenis penelitian deskriptif. Dengan menggunakan pendekatan kwalitatif, hasil penelitian ini diharapkan dapat mendeskripsikan peningkatkan kemampuan peserta PPP Program Studi Pendidikan Bahasa Inggris Unesa 2016 dalam menyusun model penilaian pembelajaran Bahasa Inggris yang dimulai dari merencanakan, mengembangkan dan menerapkan asesmen otentik.

\section{HASIL DAN PEMBAHASAN}

Di bagian ini akan disajikan hasil dan pembahasan penelitian. Diawali dengan hasil dan dilanjutkan dengan pembahasan. Terdapat tiga tahap di bagian hasil penelitian dan pembahasan, yaitu: pertama, hasil penelitian dan pembahasan tahap perencanaan; kedua, hasil penelitian dan pembahasan tahap pengembangan; dan ketiga, hasil 
penelitian dan pembahasan tahap penerapan. Berikut ini secara berurutan disampaikan ketiga tahap hasil dan pembahasan tersebut.

\section{Tahap Perencanaan}

Peserta PPP secara berkelompok menyusun perangkat pembelajaran sebelum mereka mengikuti rekaman micro-teaching. Di program studi Pendidikan Bahasa Inggris terdapat delapan kelompok yang mengikuti rekaman micro-teaching. Setelah dicermati satu per satu perangkat pembelajaran yang telah mereka selesaikan sebelum mengikuti rekaman micro-teaching, terdapat tiga kelompok perangkat pembelajaran di bagian asesmen, sebagai berikut: perangkat pembelajaran dengan asesmen yang lengkap (dua jenis asesmen ada di perangkat pembelajaran), perangkat pembelajaran dengan asesmen kurang lengkap (cenderung satu jenis asesmen di perangkat pembelajaran), dan perangkat pembelajaran tidak lengkap (satu jenis asesmen dan tidak lengkap). Ketika melakukan perencaan penyusunan asesmen yang secara eksplisit juga merupakan perencaan penyusunan perangkat pembelajaran, berdasarkan data hasil observasi ditemukan bahwa peserta PPP kebanyakan tidak / belum menerapkan lima langkah yang merupakan panduan perencanaan penyusunan instrumen asesmen, yaitu:

1) Mengidentifikasi semua langkahlangkah penting yang diperlukan.

2) Menuliskan perilaku kemampuankemampuan spesifik yang penting dan diperlukan.

3) Mengusahakan untuk membuat kriteria-kriteria kemampuan yang akan diukur.

4) Mendefinisikan dengan jelas kriteria kemampuan yang akan diukur.
5) Mengurutkan kriteria kemampuan yang akan diukur berdasarkan urutan yang dapat diamati.

Ada kecenderungan para peserta PPP yang sedang mengikuti kegiatan workshop untuk memilih cara yang pragmatis saja, yaitu mencari contoh asesmen dari internet setelah menemukan contoh asesmen kemudian mengadopsi contoh asesmen tersebut tanpa mencermatinya. Kecenderungan ini dilakukan sebagian besar kelompok peserta workshop PPP. Ketika ditanya mengapa langkah tersebut dilakukan (mengadopsi contoh asesmen dari internet), jawaban yang diterima ialah para peserta workshop PPP masih beranggapan kegiatan workshop hanya formalitas belaka. Alasan lain yang mengemuka ketika mereka, para peserta workshop PPP, diwawancarai berpendapat bahwa kegiatan workshop PPP yang dilakukan di auditorium FBS Unesa ini, dari pertimbangan alokasi waktu kurang memberi kesempatan bagi para peserta workshop PPP untuk berlatih secara leluasa setelah mereka menerima materi asesmen dari narasumber. Hasilnya tagihan asesmen yang diserahkan ke panitia kegiatan workshop PPP bidang asesmen rata-rata kurang optimal (pekerjaan asesmen para peserta).

Setelah mengikuti workshop para peserta PPP selanjutnya mendapat bimbingan yang lebih intensif dengan DPS maing-masing. Bimbingan dengan DPS berlangsung kurang lebih satu semester sampai mereka berangkat melaksanakan kegiatan PPP di sekolah mitra Unesa.

Berikut ini diuraikan hasil penelitian selama peserta PPP mengikuti bimbingan dari DPS. Pada tahap perencanaan yang dipandu oleh DPS dengan mengacu pada bekal workshop, para peserta PPP menyusun draf asesmen, sebagai berikut: 


\section{Draft penyusunan asesmen}

a. Menentukan jenis asesmen: tes dan non tes.

b. Model tes: tes uraian dan multiple choice (obyektif tes).

c. Multiple choice (obyektif tes): menjawab singkat, melengkapi, memilih, dan menjodohkan.

d. Model non tes: questioner (angket) dan lembar pengamatan.

e. Menentukan questioner: open ended questioner and closed questioner

f. Menetukan lembar pengamatan: terstruktur dan tidak terstruktur.

Langkah yang cukup baik para peserta PPP sudah memulai penyusunan perangkat pembelajaran dengan menyusun draf awal dulu. Dengan menyusun draf tersebut langkah-langkah dan/atau kegiatan-kegiatan berikutnya akan tersusun secara sistematis dan terencana. Kerangka kegiatan pembelajaran sudah dapat dicermati dari kegiatan penyusunan draf awal tersebut. Tantangan dan kendala yang muncul ketika penyusunan draf perangkat pembelajaran dengan fokus penyusunan asesmen ialah para peserta PPP kebanyakan belum / kuang banyak berlatih menyusun asesmen yang menjadi salah satu bagian dari perangkat pembelajaran. Hasil penyusunan yang diperoleh sebagian peserta PPP belum / tidak mengembangkan kisi-kisi asesmen berdasarkan indikator dan/atau tujuan pembelajaran. Asesmen sudah tersusun lebih dahulu dan menurut mereka, para peserta PPP, penyusunan asesmen sudah selesai. Ketika dosen pembimbing simulasi (DPS) memeriksa hasil pengembangan aasesmen mereka, dengan cara memeriksa ulang keterkaitan antara asesmen dengan indikator dan/atau tujuan pembelajaran, hasilnya kebanyakan instrumen asesmen tidak sinkron dengan indikator dan/atau tujuan pembelajaran. Maka saran DPS kepada peserta PPP ialah melakukan revisi draf yang sudah disusun sebelum mengembangkannya menjadi instrumen asesmen. Berikut ini disajikan hasil revisi draf penyusunan asesmen (hasil dan proses).

2. Hasil revisi draft penyusunan asesmen (hasil dan proses)

a. Asesmen Hasil (Product Assessment)

1) Format-format Tes (Test Formats)

a) Menjawab Singkat (Short-Answer)
(1) Format tak Terstruktur (Unstructured Format)
(2) Format melengkapi (Completion Format)
(3) Format Benar Salah (True-false Format)
(4) Format Pilihan Ganda (Multiple Choice Format)
(5) Format Menjodohkan (Matching Format)

b) Esai/Uraian (Essay)

(1) Format soal uraian/esai pada level aplikasi (Items to measure application)

(2) Format soal uraian/esai pada level analisis (Items to measure analysis)

(3) Format soal uraian/esai pada level sintesis (Items to measure synthesis)

(4) Format soal uraian/esai pada level evaluasi (Items to measure evaluation)

b. Asesmen Proses (Process Assessment)

Setelah menerima bimbingan dan arahan dari DPS maka hasil revisi draf penyusunan asesmen dapat dicermati seperti di angka 2 dengan judul Hasil revisi draft penyusunan asesmen (hasil dan proses). DPS membimbing peserta PPP untuk lebih fokus dalam penyusunan instrumen asesmen dengan langkah menentukan asesmen hasil terlebih 
dahulu. Dari asesmen hasil kemudian dikembangkan ke dalam format tes. Format tes kemudian dikembangkan/ dijabarkan menjadi dua bagian: menjawab singkat dan esai. Pada bagian menjawab singkat dijabarkan menjadi lima bagian, yaitu format tidak terstruktur, melengkapi, benar salah, pilihan ganda, dan menjodohkan. Sementara itu, di bagian esai dijabarkan menjadi empat bagian, yaitu: butir-butir soal untuk mengukur aplikasi, analisis, sintesis, dan evaluasi. Secara lebih lengkap dan terpetakan dengan lebih jelas bisa dicermati di bagian angka 2. Hasil revisi draft penyusunan asesmen (hasil dan proses) terbukti lebih membantu para peserta PPP dalam mengembangkan instrumen asesmen bila dibandingkan dengan draf awal yang sebelumnya. Kejelasan format tes yang telah tersusun berkontribusi positif kepada para peserta PPP. Jika para peserta PPP sudah mengkonsultasikan hasil revisi draf perencanaan instrumen asesmen dan sudah disetujui oleh DPS mereka, maka perencanaan instrumen asesmen mereka dapat dinyatakan lengkap dan layak. Peserta PPP dapat dinyatakan sudah memiliki pengetahuan dan keterampilan menyusun rencana asesmen. Para peserta PPP dapat mengikuti tahap berikutnya yaitu mengembangkan instrumen asesmen yang akan dibahas di bagian hasil dan pembahasan berikutnya.

\section{Hasil dan Pembahasan tahap Pengembangan}

Di bagian hasil dan pembahasan tahap pengembangan ini disajikan hasil dan pembahasan tahap pengembangan instrumen asesmen hasil dan proses. Kedua jenis instrumen asesmen, baik hasil maupun proses, telah dikembangkan dan sekaligus dibahas secara berurutan. Berikut ini disajikan hasil jenis-jenis instrumen asesmen hasil (product) dan instrumen proses tahap pengembangan.

\section{Mengembangkan asesmen hasil}

a. Menjawab Singkat (Short-Answer)

1) Format tak Terstruktur

(Unstructured Format)

Butir tes dapat dijawab dengan kata, frasa, atau angka.

Answer the following questions using your own words.

1. When did the man return home?

2. How did he get to his tent?

3. ...

Dalam pengembangan butir-butir instrumen bagian pertama ini, format tidak terstruktur, para peserta PPP dengan dipandu DPS mereka masing-masing relatif bisa melakukan pengembangan butir-butir instrumen asesmen tersebut dengan mudah. Panduan utama butirbutir instrumen asesmen dikembangkan dengan tahapan sebagai berikut: diawali dengan kata tanya inisial W (when, where, why, what, dan who) dan $\mathrm{H}$ (how). Kemudian ditindaklanjuti dengan pengidentifikasian pola kalimat tanya, pemilihan, penentuan, dan diakhiri dengan penulisan kalimat tanya. Perkiraan jawaban yang akan diberikan jika kalimat tanya tersebut disampaikan bisa berupa kata, frasa, atau angka. Sehingga kesesuaian antara kalimat tanya dengan jawaban yang akan diterima sudah diperkirakan sebelumnya. Demikianlah hasil temuan yang dideskripsikan pada pengembangan butirbutir instrumen asesmen pada bagian ini. Penulisan butir-butir asesmen format tak terstruktur selesai, tahapan berikutnya melaksanakan bimbingan dengan DPS untuk mendapatkan saran, input, dan koreksi untuk perbaikan butir-butir asesmen format tak terstruktur. 
Bimbingan dengan DPS selesai, langkah berikutnya merevisi butir-butir asesmen format tak terstruktur sesuai dengan saran, input, dan koreksi dari DPS.

\section{2) Format Melengkapi (Completion Format)}

Siswa menambahkan kata/frasa ke dalam kalimat yang tidak lengkap.

Complete each of the following sentences based on the above text.

1. Once there was a ... who had two servants.

2. The king said that he had like ... captains.

3. ...

Dalam pengembangan butir-butir instrumen bagian kedua ini, format melengkapi, para peserta PPP dengan dipandu DPS mereka masing-masing bisa melakukan pengembangan butir-butir instrumen asesmen tersebut dengan memperhatikan beberapa pertimbangan, antara lain: peserta PPP sudah mengidentifikasi satu dan/atau beberapa teks, memilih beberapa teks, menentukan satu dan/atau beberapa jenis teks yang akan dijadikan acuan dalam mengembangkan butir-butir instrumen asesmen format melengkapi. Mengacu pada teks maka beberapa kalimat yang akan dijadikan kisi-kisi instrumen format melengkapi terdiri dari dua jenis kalimat, yaitu kalimat yang tersurat dan tersirat di teks. Dari dua jenis kalimat tersebut langkah berikutnya dijabarkan menjadi butir-butir instrumen format melengkapi. Jika kedua jenis kalimat, tersurat dan tersirat, dipertimbangkan sama dalam pembobotan banyaknya butir-butir instrumen melengkapi, maka jumlah butir-butir yang dijabarkan dari kisi-kisi instrumen format melengkapi juga sama. Akan tetapi, jika pembobotan berbeda, maka penjabaran jumlah butir-butir penjabaran instrumen format melengkapi juga berbeda. Ketentuan tersebut sudah direncanakan dalam pemetaan kisi-kisi instrumen format melengkapi. Jadi, jika diperiksa ulang jumlah pengembangan butir-butir instrumen format melengkapi sejalan dengan pemetaan yang sudah dilakukan sebelumnya. Penulisan butirbutir asesmen format melengkapi selesai, tahapan berikutnya melaksanakan bimbingan dengan DPS untuk mendapatkan saran, input, dan koreksi untuk perbaikan butir-butir asesmen format melengkapi. Bimbingan dengan DPS selesai, langkah berikutnya merevisi butir-butir asesmen format melengkapi sesuai dengan saran, input, dan koreksi dari DPS.

\section{3) Format Benar Salah (True-False} Format)

Butir tes menyediakan dua jawaban pilihan.

Check $(\sqrt{ })$ the box on the right side of each sentence. Check $T$ (true) if the statement is true and $F$ (false) if it is wrong.

Tabel 2. Format Soal Benar Salah

\begin{tabular}{|c|l|c|c|}
\hline No. & \multicolumn{1}{|c|}{ Statement } & T & F \\
\hline 1 & In a moment the sun will set in the east. & & \\
\hline 2 & The sun rotates around the earth. & & \\
\hline
\end{tabular}

Dalam pengembangan butir-butir instrumen bagian ketiga ini, format benar salah, para peserta PPP dengan dipandu
DPS mereka masing-masing bisa melakukan pengembangan butir-butir instrumen asesmen tersebut dengan 
memperhatikan beberapa pertimbangan, antara lain: pernyataan-pernyataan yang disusun dan dikembangkan mengacu pada fakta dan/atau realita sehari-hari yang bisa dibenarkan dan/atau disalahkan secara logika akal sehat dan yang berikutnya pernyataan-pernyataan yang disusun dan dikembangkan berdasarkan isi suatu teks. Oleh karena itu contoh yang dikemukakan di dalam pembahasan bagian ini mengacu pada pernyataanpernyataan yang pertama, mengacu pada logika akal sehat semata. Sementara itu, DPS selalu memeriksa secara intensif dan berkelanjutan penyusunan kisi-kisi dan butir-butir instrumen format benar salah yang dikembangkan oleh peserta PPP. Instruksi yang disusun untuk memandu dalam mengerjakan butir-butir asesmen format benar salah harus cermat, teliti dan sesuai. Penulisan butir-butir asesmen format benar salah selesai, tahapan berikutnya melaksanakan bimbingan dengan DPS untuk mendapatkan saran, input, dan koreksi untuk perbaikan butirbutir asesmen format benar salah. Bimbingan dengan DPS selesai, langkah berikutnya merevisi butir-butir asesmen format benar salah sesuai dengan saran, input, dan koreksi dari DPS.

4) Format Pilihan Ganda (Multiple Choice

Format)

The test items provides answers (options) to be selected.

Cross the letter $A, B, C, D$, or $E$ that best

answers the question.

1. How many tourists are mentioned in the first paragraph?
A. Three.
C. Five.
E. Seven
B. Four
D. Six

Dalam pengembangan butir-butir instrumen bagian keempat ini, format pilihan ganda, para peserta PPP dengan dipandu DPS mereka masing-masing bisa melakukan pengembangan butir-butir instrumen asesmen tersebut dengan memperhatikan beberapa pertimbangan, antara lain: peserta PPP menyusun kisi- kisi asesmen format pilihan ganda. Tahap berikutnya menentukan jumlah kisi-kisi asesmen format pilhan ganda. Kemudian, dilanjutkan dengan langkah berikutnya, yaitu pemberian bobot pada masingmasing kisi-kisi asesmen format pilihan ganda, bobotnya sama dan/atau berbeda untuk masing-masing kisi-kisi asesmen format pilihan ganda. Setelah diputuskan sama dan/atau berbeda, maka langkah berikutnya pengembangan butir-butir asesmen format pilihan ganda sesuai dengan penentuan kisi-kisi instrumen format pilihan ganda. Hal ini penting diperhatikan bagi peserta PPP, karena kesesuaian antara penyusunan kisi-kisi instrumen format pilihan ganda dengan pengembangan butir-butir instrumen format pilihan ganda harus berkelanjutan, sehingga representasi jumlah pengembangan butir-butir asesmen format pilihan ganda bisa dipertanggungjawabkan secara akademis. Penulisan butir-butir asesmen format pilihan ganda selesai, tahapan berikutnya melaksanakan bimbingan dengan DPS untuk mendapatkan saran, input, dan koreksi untuk perbaikan butir-butir asesmen format pilihan ganda. Bimbingan dengan DPS selesai, langkah berikutnya merevisi butir-butir asesmen format pilihan ganda sesuai dengan saran, input, dan koreksi dari DPS.

5) Format Menjodohkan (Matching Format) Testees are required to match each of the words on the left column to the one on the right.

Which word on the left column matches to that on the right? Draw a line to indicate your answer

Table 3. Format Soal Menjodohkan
a. An apple
1 . vegetables
b. A table
2. transportation
c. A plane
3. furniture
d. A pencil
4. climate
e. ...
5. ...

Dalam pengembangan butir-butir instrumen bagian kelima ini, format 
menjodohkan, para peserta PPP dengan dipandu DPS mereka masing-masing bisa melakukan pengembangan butir-butir instrumen asesmen tersebut dengan memperhatikan beberapa pertimbangan, antara lain: prinsip utama asesmen format menjodohkan harus memperhatikan kedua belah pihak mempunyai lebih banyak persamaan daripada perbedaan. Contoh yang disajikan dalam bagian ini menunjukkan satu kosakata berkolerasi erat dengan kosakata yang lain. Korelasi terjadi karena kedua kosakata tersebut mempunyai banyak kemiripan baik dari sisi substansi maupun maknanya. Para peserta PPP dipandu oleh DPS mereka dengan menyebut istilah yang sudah akrab dengan mereka, peserta PPP, yaitu sinonim atau padanan kata. Disisi yang lain, mereka, peserta PPP, juga sudah akrab dengan istilah antonim, lawan kata. Jadi peserta PPP dalam menyusun kisikisi asesmen format menjodohkan harus mengidentifikasi dulu, sebagai langkah awal, beberapa pertimbangan, antara lain peserta PPP harus mengenali persamaan kelas kata, arti kata secara leksikal, dan makna kata secara kontekstual jika kata dan/atau kosakata tersebut sudah menjadi satu unsur dalam kalimat. Langkah berikutnya baru mengembangkan kisikisi asesmen format menjodohkan menjadi butir-butir asesmen format menjodohkan. Kemudian ditindaklanjuti dengan pembobotan jumlah butir-butir asesmen format menjodohkan. Setelah pembobotan selesai, tahapan berikutnya penulisan butir-butir asesmen format menjodohkan dengan mengacu pada pembobotan jumlah butir-butir asesmen format menjodohkan. Penulisan butirbutir asesmen format menjodohkan selesai, tahapan berikutnya melaksanakan bimbingan dengan DPS untuk mendapatkan saran, input, dan koreksi untuk perbaikan butir-butir asesmen format menjodohkan. Bimbingan dengan DPS selesai, langkah berikutnya merevisi butir-butir asesmen format menjodohkan sesuai dengan saran, input, dan koreksi dari DPS.

b. Tipe Esai/Uraian (Essay Types)

1) Pengukuran level Aplikasi (Measuring Application)

To measure application:

You are in charge of planning meals and ordering food for a three-day camping. Write out menus for the occasion: three day of breakfasts, lunches, and suppers. Explain why you made your choices.

Dalam pengembangan butir-butir instrumen bagian $b$ tipe esai ini, format uraian dengan level aplikasi, para peserta PPP dengan dipandu DPS mereka masing-masing berusaha tahap demi tahap untuk melakukan pengembangan butir-butir instrumen asesmen tipe uraian pada level aplikasi dengan memperhatikan beberapa pertimbangan, antara lain: level aplikasi keterampilan berbahasa Inggris harus sesuai dengan kemampuan siswa SMP sehingga pertanyaan yang disusun harus mengacu pada KI dan KD siswa SMP. Dengan mengacu pada KI dan KD SMP maka pertanyaan jenis esai diidentifikasi, di pilih/seleksi, ditetapkan, dan ditulis menjadi satu pertanyaan jenis esai untuk siswa SMP. Penulisan butir-butir asesmen tipe esai selesai, tahapan berikutnya melaksanakan bimbingan dengan DPS untuk mendapatkan saran, input, dan koreksi untuk perbaikan butirbutir asesmen tipe esai pada level aplikasi. Bimbingan dengan DPS selesai, langkah berikutnya merevisi butir-butir asesmen tipe esai level aplikasi sesuai dengan saran, input, dan koreksi dari DPS.

2) Pengukuran level Analisis (Measuring Analysis)

To measure analysis:

You have just watched a TV program on how to study in a university. Write an account of what you have just seen, explain what they 
were all about, and why they were so. Draw a diagram to make your account easier to understand.

Dalam pengembangan butir-butir instrumen bagian $b$ tipe esai ini, format uraian dengan level analisis, para peserta PPP dengan dipandu DPS mereka masing-masing berusaha tahap demi tahap untuk melakukan pengembangan butir-butir instrumen asesmen tipe uraian pada level analisis dengan memperhatikan beberapa pertimbangan, antara lain: level analisis keterampilan berbahasa Inggris harus sesuai dengan kemampuan siswa SMP sehingga pertanyaan yang disusun harus mengacu pada KI dan KD siswa SMP. Dengan mengacu pada KI dan KD SMP maka pertanyaan jenis esai diidentifikasi, di pilih/seleksi, ditetapkan, dan ditulis menjadi satu pertanyaan jenis esai untuk siswa SMP. Penulisan butir-butir asesmen tipe esai selesai, tahapan berikutnya melaksanakan bimbingan dengan DPS untuk mendapatkan saran, input, dan koreksi untuk perbaikan butirbutir asesmen tipe esai pada level analisis. Bimbingan dengan DPS selesai, langkah berikutnya merevisi butir-butir asesmen tipe esai level analisis sesuai dengan saran, input, dan koreksi dari DPS.

3) Pengukuran level Sintesis (Measuring Synthesis)

To measure synthesis:

You are assigned to organize a group of your classmates to collect donation for an earthquake disaster. Plan, describe, and explain how you will do all about it.

Dalam pengembangan butir-butir instrumen bagian $b$ tipe esai ini, format uraian dengan level sintesis, para peserta PPP dengan dipandu DPS mereka masing-masing berusaha tahap demi tahap untuk melakukan pengembangan butir-butir instrumen asesmen tipe uraian pada level sintesis dengan memperhatikan beberapa pertimbangan, antara lain: level sintesis keterampilan berbahasa Inggris harus sesuai dengan kemampuan siswa SMP sehingga pertanyaan yang disusun harus mengacu pada KI dan KD siswa SMP. Dengan mengacu pada KI dan KD SMP maka pertanyaan jenis esai diidentifikasi, di pilih/seleksi, ditetapkan, dan ditulis menjadi satu pertanyaan jenis esai untuk siswa SMP. Penulisan butir-butir asesmen tipe esai selesai, tahapan berikutnya melaksanakan bimbingan dengan DPS untuk mendapatkan saran, input, dan koreksi untuk perbaikan butirbutir asesmen tipe esai pada level sintesis. Bimbingan dengan DPS selesai, langkah berikutnya merevisi butir-butir asesmen tipe esai level sintesis sesuai dengan saran, input, dan koreksi dari DPS.

4) Pengukuran level Evaluasi (Measuring Evaluation)

To measure evaluation:

Below is a poem written by R. Frost. Write an essay of about 300 words to evaluate it.

Dalam pengembangan butir-butir instrumen bagian $b$ tipe esai ini, format uraian dengan level evaluasi, para peserta PPP dengan dipandu DPS mereka masing-masing berusaha tahap demi tahap untuk melakukan pengembangan butir-butir instrumen asesmen tipe uraian pada level evaluasi dengan memperhatikan beberapa pertimbangan, antara lain: level evaluasi keterampilan berbahasa Inggris harus sesuai dengan kemampuan siswa SMP sehingga pertanyaan yang disusun harus mengacu pada KI dan KD siswa SMP. Dengan mengacu pada KI dan KD SMP maka pertanyaan jenis esai diidentifikasi, di pilih/seleksi, ditetapkan, dan ditulis menjadi satu pertanyaan jenis esai untuk siswa SMP. Penulisan butir-butir asesmen tipe esai selesai, tahapan berikutnya melaksanakan bimbingan dengan DPS untuk mendapatkan saran, 
input, dan koreksi untuk perbaikan butirbutir asesmen tipe esai pada level evaluasi. Bimbingan dengan DPS selesai, langkah berikutnya merevisi butir-butir asesmen tipe esai level evaluasi sesuai dengan saran, input, dan koreksi dari DPS.

\section{Mengembangkan Instrumen Asesmen Proses}

Di bagian ini disajikan instrumen asesmen proses berupa lembar pengamatan kelas. Hanya terdapat satu hasil yang merupakan contoh instrumen asesmen proses. Seperti pada instrumen asesmen hasil, di bagian ini disajikan hasil isntrumen asesmen hasil kemudian diteruskan dengan pembahasan. Berikut ini disajikan hasil instrumen asesmen proses, lembar pengamatan kelas, dan sekaligus pembahasannya.

Lembar Pengamatan Kelas

Kelas /Semester $\quad: \ldots$

Mata pelajaran $\quad: \ldots$

Periode Pengamatan: ...... s.d. ......

Petunjuk pengisian:

Berikan penilaian Anda dengan membubuhkan tanda koreksi $(\sqrt{ })$ di dalam kolom yang disediakan: $\mathrm{T}=$ Tinggi, $\mathrm{S}=$ Sedang, dan $\mathrm{R}=$ Rendah.

Tabel 4. Lembar Pengamatan Kelas

\begin{tabular}{|l|c|c|c|c|}
\hline \multicolumn{1}{|c|}{$\begin{array}{c}\text { Nama } \\
\text { Siswa }\end{array}$} & Grammar & Pronunciation & Vocabulary & $\ldots \ldots \ldots \ldots . .$. \\
\hline 1. & & & & \\
\hline 2. & & & & \\
\hline
\end{tabular}

Dalam pengembangan butir-butir instrumen proses bagian ini, lembar pengamatan kelas, para peserta PPP dengan dipandu DPS mereka masingmasing berusaha tahap demi tahap untuk melakukan pengembangan butir-butir instrumen asesmen proses dengan memperhatikan beberapa pertimbangan, antara lain: para peserta PPP mencermati aspek pengamatan meliputi tata bahasa (grammar), keakuratan (accuracy) ucapan, kosakata (vocabulary), dan keterampilan berbahasa Inggris harus sesuai dengan kemampuan siswa SMP sehingga aspek-aspek yang diamati harus mengacu pada KI dan KD siswa SMP. Dengan mengacu pada KI dan KD SMP maka penyusunan aspek-aspek asesmen proses diidentifikasi, dipilih/seleksi, ditetapkan, dan ditulis menjadi satu lembar pengamatan kelas siswa SMP. Penulisan lembar pengamatan kelas selesai, tahapan berikutnya melaksanakan bimbingan dengan DPS untuk mendapatkan saran, input, dan koreksi untuk perbaikan aspek-aspek pengamatan asesmen proses. Bimbingan dengan DPS selesai, langkah berikutnya merevisi aspek-aspek pengamatan asesmen proses sesuai dengan saran, input, dan koreksi dari DPS.

Jika peserta PPP sudah berkonsultasi dengan DPS dan mendapat persetujuan sehingga dinyatakan bahwa hasil pengembangan dua jenis asesmen, yaitu asesmen hasil dan proses, dinyatakan lengkap dan layak, maka peserta PPP sudah dapat dinyatakan mempunyai pengetahuan dan keterampilan untuk mengembangkan instrumen asesmen. Selanjutnya, mereka dapat mengikuti tahap berikutnya yaitu tahap penerapan instrumen asesmen. Bagian berikut ini akan disajikan hasil dan pembahasan tahap penerapan.

\section{Tahap Penerapan}

Di bagian ini disajikan hasil dan pembahasan tahap penerapan instrumen asesmen. Dalam menerapkan instrumen 
asesmen diperlukan enam pertimbangan oleh para peserta PPP sebagai penyusun instrumen asesmen pemula, antara lain:

1) Pemilihan Bentuk Tes

2) Jumlah peserta (siswa)

3) Kesulitan/kemudahan penyusunan

4) Kesulitan/kemudahan penyekoran

5) Jumlah materi yang diujikan

6) Tingkat kesulitan materi yang diujikan

Ketika menerapkan instrumen asesmen, baik asesemen hasil dan/atau asesmen proses, peserta PPP harus mempertimbangkan enam hal di atas. Penerapan instrumen asesmen lebih banyak dilakukan peserta PPP ketika mereka sudah menjalani paraktek PPP di sekolah mitra Unesa. Di sekolah mitra Unesa, peserta PPP lebih banyak dan intensif menerima pendampingan dari guru pamong mereka. Dari mulai perencanaan perangkat pembelajaran, pengimplementasian, dan evaluasi; mereka, peserta PPP, selalu berkonsultasi dengan guru pamong mereka. Dalam menerapkan instrumen asesmen di sekolah yang merupakan salah satu bagian yang ada di perangkat pembelajaran peserta PPP harus berkonsultasi dengan guru pamong mereka. Konsultasi bisa dilakukan sebelum, selama, dan sesudah praktek mengajar di sekolah mitra Unesa. Ketika menyusun perangkat pembelajaran yang salah satu bagiannya terdapat asesmen, peserta PPP berkonsultasi dengan guru pamong mereka dengan memperhaikan enam hal di atas, yaitu:

1) Pemilihan bentuk tes.

Di bagian pemilihan bentuk tes ada pedoman utama yang harus dipahami oleh peserta PPP ialah bentuk tes yang dipilih adalah bentuk tes yang paling mudah bagi penyusun dan biaya untuk menyusunnya selalu diupayakan yang paling murah. Dua hal tersebut harus dijadikan pedoman bagi penyusun instrumen tes. Dari beberapa bentuk tes yang sudah diuraikan di bagian pembahasan sebelumnya, penyusun tes harus selektif dalam memilih bentuk tes.

2) Jumlah peserta (siswa)

Di bagian jumlah peserta/siswa, peserta PPP dengan bimbingan dari guru pamong di sekolah mitra Unesa harus mengetahui secara pasti berapa jumlah peserta/siswa yang akan mengikuti tes. Hal ini penting dipertimbangkan karena berkaitan dengan tahapan berikutnya dalam proses mulai persiapan, penyusunan, penerapkan/pelaksanaan, dan pemeriksaan hasil tes.

3) Kesulitan/kemudahan penyusunan

Ketika jumlah tujuan pembelajaran sudah diketahui secara pasti, maka langkah selanjutnya ialah sejumlah tujuan pembelajaran tadi dijadikan kisi-kisi instrumen tes. Setelah jumlah kisi-kisi ditetapkan maka setiap kisi-kisi diberi bobot masing-masing. Hasil pembobotan setiap kisi-kisi dijabarkan menjadi jumlah butir-butir instrumen tes. Berapa jumlah setiap butir-butir instrumen tes harus dirujuk dengan rencana jumlah butir-butir instrumen tes secara menyeluruh yang sudah ditetapkan oleh penyusun tes. Dengan pemetaan seperti itu, penyusunan butir-butir instrumen tes akan lebih mudah jika dibandingkan dengan tanpa melakukan pemetaan. Setelah melakukan konsultasi dengan guru pamong, peserta PPP melakukan revisi sesuai dengan saran, input/ masukan, dan koreksi yang telah diberikan oleh guru pamong mereka terutama terkait dengan kesulitan dan/atau kemudahan penyusunan butirbutir tes.

4) Kesulitan/kemudahan penskoran

Dengan mengacu pada prosentase setiap kisi-kisi soal, maka pemetaan penskoran hasil tes telah dilakukan. Dengan pemetaan seperti itu, penskoran 
hasil tes akan lebih mudah dilaksanakan jika dibandingkan dengan tanpa melakukan pemetaan. Jika pemetaan penskoran hasil tes pada bagian ini telah dilakukan, maka peserta PPP melaksanakan konsultasi dengan guru pamong untuk menerima saran, input/masukan, dan koreksi terutama terkait dengan kesulitan dan/atau kemudahan penskoran hasil tes. Setelah melakukan konsultasi dengan guru pamong, peserta PPP melakukan revisi sesuai dengan saran, input/ masukan, dan koreksi yang telah diberikan oleh guru pamong mereka terutama terkait dengan kesulitan dan/atau kemudahan penskoran hasil tes.

5) Jumlah materi yang diujikan

Hasil pembobotan dan/atau prosentase setiap kisi-kisi dijabarkan menjadi jumlah butir-butir instrumen tes. Berapa jumlah butir-butir instrumen tes harus dirujuk dengan rencana jumlah butir-butir instrumen tes secara menyeluruh dan diperkirakan dengan alokasi waktu tes yang sudah ditetapkan oleh penyusun tes juga. Dengan mengacu pada prosentase setiap kisi-kisi soal, maka pemetaan jumlah materi dan/atau pokok bahasan yang diujikan dan alokasi waktu yang tersedia untuk melaksanakan tes telah dilakukan. Dengan pemetaan seperti itu, jumlah materi dan/pokok bahasan yang diujikan dan alokasi waktu yang tersedia untuk melaksanakan tes akan lebih mudah diketahui jika dibandingkan dengan tanpa melakukan pemetaan. Setelah melakukan konsultasi dengan guru pamong, peserta PPP melakukan revisi sesuai dengan saran, input/ masukan, dan koreksi yang telah diberikan oleh guru pamong mereka terutama terkait dengan jumlah materi dan/atau pokok bahasan yang diujikan.

6) Tingkat kesulitan materi yang diujikan
Berapa jumlah butir-butir instrumen tes yang sesuai dengan jenis format tes harus dikembangkan merujuk pula dengan hasil pemeringkatan tingkat kesulitan setiap kisi-kisi tes serta dengan rencana jumlah butir-butir instrumen tes secara menyeluruh. Dengan mengacu pada hasil pemeringkatan tingkat kesulitan setiap kisi-kisi tes yang sesuai dengan jenis format tes, maka pemetaan pemeringkatan tingkat kesulitan setiap kisi-kisi tes telah dilakukan. Dengan pemetaan seperti itu, tingkat kesulitan materi dan/pokok bahasan yang diujikan dan penentuan jenis format tes lebih mudah diketahui jika dibandingkan dengan tanpa melakukan pemetaan. Setelah melakukan konsultasi dengan guru pamong, peserta PPP melakukan revisi sesuai dengan saran, input/ masukan, dan koreksi yang telah diberikan oleh guru pamong mereka terutama terkait dengan tingkat kesulitan materi dan/atau pokok bahasan dan penentuan jenis format tes yang diujikan.

Jika keenam jenis pertimbangan, yaitu pemilihan bentuk tes, jumlah peserta (siswa), kesulitan/kemudahan penyusunan, kesulitan/kemudahan penyekoran, jumlah materi yang diujikan, dan tingkat kesulitan materi yang diujikan sudah dilakukan secara bertahap dan tuntas, maka instrumen asesmen sudah siap untuk diaplikasikan. Sehingga peserta PPP sudah dapat dinyatakan mempunyai pengetahuan dan keterampilan yang layak untuk menerapkan instrumen asesmen di SMP.

\section{SIMPULAN DAN SARAN Simpulan}

Mengacu pada hasil penelitian dan pembahasan yang telah dilakukan, terdapat tiga kesimpulan, sebagai berikut:

- Peserta PPP Program Studi Pendidikan Bahasa Inggris ketika melaksanakan 
penyusunan perangkat pembelajaran yang di salah satu bagiannya terdapat asesmen, hasil perencanaan penyusunan instrumen asesmen mereka terbagi menjadi tiga kelompok utama, yaitu: perencanaan asesmen lengkap, kurang lengkap, dan tidak lengkap.

- Peserta PPP Program Studi Pendidikan Bahasa Inggris ketika melaksanakan penyusunan perangkat pembelajaran yang di salah satu bagiannya terdapat asesmen, hasil pengembangan instrumen asesmen mereka terbagi menjadi tiga kelompok utama, yaitu: pengembangan asesmen lengkap, kurang lengkap, dan tidak lengkap.

- Peserta PPP Program Studi Pendidikan Bahasa Inggris ketika melaksanakan KBM di kelas yang di salah satu tahapannya terdapat penerapan instrumen asesmen di KBM, hasil penerapan instrumen asesmen mereka di KBM terbagi menjadi tiga kelompok utama, yaitu: penerapan yang tepat, kurang tepat, dan tidak tepat.

\section{Saran}

Berdasarkan hasil penelitian dan pembahasan di bab sebelumnya, terdapat tiga saran dalam laporan penelitian ini, yang ditujukan kepada:

- Mahasiswa calon peserta PPP.

Mengacu pada kesimpulan yang telah di utarakan di bagian sebelumnya maka mahasiswa calon peserta PPP sebaiknya selektif dalam membaca laporan hasil PPP yang disusun oleh kakak angkatan mereka.

- Guru pamong pendamping PPP di sekolah mitra Unesa.

Guru pamong pendamping PPP di sekolah mitra Unesa sebaiknya lebih kooperatif dan proaktif dalam melakukan pendampingan kepada mahasiswa peserta PPP 2 di sekolah mitra Unesa.

- Dosen pembimbing simulasi PPP. Dosen pembimbing simulasi PPP di prodi Pendidikan Bahasa Inggris sebaiknya lebih kooperatif dan proaktif dalam melaksanakan pembimbingan simulasi PPP kepada mahasiswa peserta PPP 1 dan PPP 2, ketika mereka (peserta PPP) di prodi Pendidikan Bahasa Inggris maupun di sekolah mitra Unesa.

\section{DAFTAR PUSTAKA}

Burhan Nurgiyantoro. 2001. Penilaian dalam Pengajaran Bahasa Indonesia.Yogyakarta: BPFE Yogyakarta.

Dantes. 2008. Hakehat Asesmen Otentik sebagai Penilain Proses dan Produk Dalam Pembelajaran yang Berbasis Kompetensi. Makalah

Depdiknas. 2003. Assesmen Autentik, Materi Pelatihan Terintegrasi Kompetensi Guru Mata Pelajaran Bahasa Inggris. Jakarta: Dikdasmen.

Hibbard, M. 1995. Performance Assessment in the Science Classroom. New York: The McGraw-Hill Companies.

Hughes, A. 1991. Testing for Language Teachers. Cambridge: Cambridge University Press.

O'Malley, J. Michael, and Lorraine Valdez Pierce. 1996. Authentic Assessment for English Language Learning: Practical Approaches for Teachers. New York: AddisonWesley Publishing.

Susanto, 2012, Assessment - materi PLPG Guru-guru Bahasa Inggris PSG Universitas Negeri Surabaya (power point). 